\title{
Adult Second Language Learners' Pragmatic Development in the Study-abroad Context: A Review
}

\author{
Feng Xiao \\ Pomona College
}

\section{Introduction}

The ability to use language effectively in communication is regarded as important as knowledge of grammatical rules in the communicative competence models (Bachman \& Palmer, 1996, 2010; Canale \& Swain, 1980). Pragmatic competence, namely the ability to understand and use linguistic forms appropriately according to context, is thus accepted as a vital component of language ability (e.g., Bachman \& Palmer, 1996, 2010). Recently, pragmatic competence and development have captured growing interest among L2 pragmatics research (for a review, see Kasper \& Rose, 1999, 2002; Kasper \& Roever, 2005; Taguchi, 2010). Specifically, a series of studies have been conducted in the study abroad (SA) context (e.g., Barron, 2003; Iwasaki, 2010; Kinginger, 2008; Matsumura, 2001, 2003; Schauer, 2006a, 2006b; Taguchi, 2008a, 2008b), because, compared to a domestic classroom setting, the SA context is believed to provide greater opportunities to communicate with native speakers, and these opportunities are assumed to lead to pragmatic gains (Kinginger, 2008, 2009). For example, expressions such as "would you+verb" and "could I +verb" are usually used to make a request, and expression like "why not+verb" and "how about +verb" are often interpreted as suggestions. This conventional language use for pragmatics is recurrent in the target-language community, providing learners more exposure to such language use and consequently, more opportunities to use such conventional pragmatic expressions in context.

Despite the greater contact with conventional pragmatic language use available in the SA context, recent longitudinal studies have shown that different aspects of pragmatic features develop at different rates. For example, Taguchi (2008b) examined Japanese ESL learners' development of pragmatic comprehension over a four-month study abroad. She found that there were significant gains in both accurate and speedy comprehension of pragmatic meaning, but the magnitude of gain in comprehension speed (measured in response time) was larger than the gain in accuracy in comprehension.

This article aims to further probe this complex relationship between the SA context and pragmatic development by synthesizing existing research studies under the guidance of two questions: 1) What pragmatic features have been examined in the SA context, and how have they been measured? and 2) Do adult L2 learners improve their pragmatic competence in the SA context over time?

\section{Terminology}

As mentioned above, the current study focuses on L2 pragmatic development in the SA context. Therefore, two key terms: pragmatic competence/development and the SA context are defined below.

\section{Pragmatic Competence and Development}

Traditionally, pragmatic competence was claimed to involve two subcomponents: pragmalinguistics (functional-linguistic aspect of pragmatic competence) and sociopragmatics (social aspect of pragmatic 
competence) (Leech, 1983; Thomas, 1983). According to Thomas (1983), pragmatic failure can be broken down into pragmalingusitc failure and sociopragmatic failure. Pragmalinguistic failure is fundamentally a linguistic problem, "caused by differences in the linguistic encoding of pragmatic force;" while sociopragmatic failure is derived from "different perceptions of what constitutes appropriate linguistic behavior." (Thomas, 1983, p.99)

These two components of pragmatic competence are found in Bachman and Palmer's (1996, 2010) model of communicative language ability, which refers to the ability to use language communicatively. According to Bachman and Palmer, pragmatic knowledge is one of the two main components of language knowledge. It consists of functional knowledge and sociolinguistic knowledge. The former represents the knowledge of linguistic forms associated with certain pragmatic functions (e.g., using "would you" to make a request), while the latter refers to the knowledge of appropriateness of forms in context (e.g., choosing polite speech style when speaking to people of higher social status). As such, pragmatic knowledge is the knowledge of the relationship between linguistic forms, functions, and appropriateness of forms in context. In other words, pragmatic knowledge involves the knowledge of form-function-context mapping.

In this synthesis paper, pragmatic competence is composed of two main components: form-function knowledge (pragmalinguistics) and sociolinguistic knowledge (sociopragmatics). Thus, the development of pragmatic competence is defined as the development of pragmatic knowledge in these two components.

\section{Study-Abroad Context}

Another important terminology in this synthesis study is study abroad (SA). In the current research, there are several definitions of the SA context (e.g., Collentine, 2009; Freed, 1995; Kinginger, 2009). Although these definitions vary in their specifics, most of them include the following common elements: outof-class exposure in a foreign country, stay in a foreign country for educational purposes, and stay in a community where the target language is widely spoken. In this paper, the SA context is defined as a temporary and pre-scheduled educational stay in a foreign country where the target language is the native language of the people in the country. Travels without educational purposes or naturalistic language acquisition in sojourns will be excluded from discussion in this paper.

\section{Method}

The following steps were taken to locate relevant studies in the database that fit the definitions of the terms presented above in this synthesis paper. First, relevant key words were chosen and sorted into two groups for the database search. Group one comprised of words related to pragmatic development, including pragmatic development, pragmatic competence, sociocultural competence, sociolinguistic competence, interactional competence, interlanguage pragmatics, pragmaliguistic competence, sociopragmatic competence, speech acts, routines, and implicatures. Group two consisted of words related to the SA context, such as study-abroad context, study abroad, and second language learning. Second, all word combinations, created by mixing each word in group one with each word in group two, were searched for in multiple databases, including Eric, LLBA, JSTOR, MLA and Sage Journals, of peer-reviewed journals and books published between 1990 and 2012. This search process yielded 367 studies, of which irrelevant studies were eliminated based on the criteria listed below. At the end, 26 studies (marked with an asterisk in references) were included in this synthesis study. 


\section{Inclusion/Exclusion Criteria}

1. The study focused on the change of pragmatic competence over time.

2. The study was a data-driven empirical study on pragmatic development.

3. The study had multiple data collection points.

4. Studies with comparison between SA and at-home groups were included if they had multiple data collection points in each group.

5. Studies using a sample of children were excluded.

6. Studies conducted in the SA context without any educational purpose were excluded.

7. Studies about instructional effects on pragmatic development in the SA context were excluded.

\section{Coding of Studies}

Following Norris \& Ortega (2006), selected 26 studies were coded for two types of study features: substantive and methodological features. The former included author and publishing date, research questions, target language, target pragmatic features, and modalities (comprehension, production or perception), while the latter included instrument/data, data collection points, sample size, L2 proficiency levels, and length of study abroad. I also coded each study for the findings in order to answer my synthesis questions (See Appendix A for details).

\section{Review of Studies on Pragmatic Development in the SA Context}

\section{Synthesis Question One}

Synthesis question one asks what pragmatic features have been examined in the SA context and how they have been measured. The following analysis will first describe pragmatic features studied in the SA context, and then summarize measures of these pragmatic features.

The main pragmatic features investigated in the SA context are speech acts (12 out of 26 studies). Several types of speech acts are targeted in these studies: request (Barron, 2003, 2007; Bataller, 2010; Cole \& Anderson, 2001; Schauer, 2006a, 2006b, 2007), apology (Warga \& Scholmeberger, 2007), suggestion and rejection (Bardovi-Harlig \& Hartford, 1993), advice-giving expressions (Matsumura, 2001, 2003), and leavetaking expressions (Kinginger, 2008). Another target pragmatic feature is comprehension of conversational implicatures (Bouton, 1992, 1994; Taguchi, 2008a, 2008b).

Another ten studies investigated sociolinguistic forms. Barron (2006) investigated German address forms sie (showing reciprocal and intimate relationship) and $d u$ (showing politeness and distance). French address form vous (showing intimate and simple relationship) and $t u$ (showing reciprocal and intimate relationship) were targeted in two studies (Kinginger \& Farrell, 2004; Kinginger, 2008). Colloquial words were investigated in two studies (Kinginger \& Blattner, 2008; Kinginger, 2008). Modal expressions (e.g., "would," and "could") were examined in one study (Salisbury \&Bardovi-Harlig, 2000).

Other sociolinguistic forms investigated in the SA context include French negation word ne (Regan, 1995), Japanese polite and plain speech style (Iwasaki, 2010), Japanese sentence final particle ne (Ishida, 2009; Masuda, 2011; Sawyer, 1992), and listeners' response forms (Ishida, 2011). Regan (1995) examined French negation word ne, which is usually used in formal style of French, but deleted in informal style of French. Similarly, Iwasaki (2010) investigated Japanese polite (masuldesu) and plain style. Also targeting Japanese, Sawyer's (1992), Ishida (2009) and Masuda (2011) examined Japanese sentence final particle ne, which has 
versatile usage such as requesting confirmation, introducing new topics and mitigating. Ishida's (2011) study focused on two types of listeners' response in L2 English: closing action and topic continuing action. Closing action refers to response to a story (e.g., presenting agreement or assessment on the interlocutor's telling). Topic continuing action involves response as a way to continue the same topic of the story told (e.g., telling a second story, giving comments on the story and making a contrastive telling).

In terms of modalities in investigation, previous studies are divided into three groups: studies that examined pragmatic production (use of target pragmatic features), comprehension (understanding of implied speakers' intentions) and perception (perceived knowledge of appropriateness of forms in situation). Among the 26 studies, 16 studies examined production (Bardovi-Harlig \& Hartford, 1993; Barron, 2003, 2006, 2007; Bataller, 2010; Cole \& Anderson, 2001; Ishida, 2009, 2011; Iwasaki, 2010; Masuda, 2011; Regan, 1995; Salsbury \& Bardovi-Harlig, 2000; Sawyer, 1992; Schauer, 2006b, 2007; Warga \& Scholmberger, 2007), four studies investigated comprehension (Bouton, 1992, 1994; Taguchi, 2008a, 2008b), and seven studies examined perception (Kinginger, 2008; Kinginger \& Farrell, 2004; Kinginger \& Blattner, 2008; Matsumura, 2001, 2003; Schauer, 2006a, 2006b).

In the 16 studies on pragmatic production, the measurements used were discourse completion task (DCT), multimedia elicitation task, role-play, oral proficiency interview (OPI), and semi-structured interview. In addition, naturalistic spoken data of audio and video recordings were used.

Three of the 16 studies about production used DCT (Barron, 2003, Cole \& Anderson, 2001; Warga \& Scholmberger, 2007). DCT has a set of brief written situations used to elicit responses that are unique to these situations. In DCT, participants read written descriptions of situations, and write down what they would say in the situations.

Like DCT, multimedia elicitation task shows written descriptions of situations, but it also present the situations visually and requires participants to give oral responses. In Schauer's (2006b, 2007) studies, participants read descriptions of situations and pictures of interlocutors on computer while hearing instructions. They were required to produce requests according to situation, and the computers automatically recorded their oral responses.

In addition to multimedia elicitation task, role-play (Bataller, 2010), OPI (Iwasaki, 2010), and semistructured interview (Regan, 1995; Sawyer, 1992) are used to collect oral data in face-to-face interactions. Bataller's (2010) study on American learners' production of Spanish requests used a role-play task with two scenarios: requesting something to drink and requesting to exchange a pair of shoes without the receipt. In the role-play, participants acted out the scenario with a native Spanish speaker. OPI was used in Iwasaki's (2010) study on American learners' production of Japanese polite and plain speech style. Participants took the OPI with a Japanese teacher, who was obviously older than the interviewers, so the appropriate speech style in interview should have been polite style. Iwasaki examined if the participants maintained the polite form throughout the interview. Semi-structured interview was used in Sawyer's (1992) study on American learners' production of Japanese sentence final particle ne. Similarly, Regan (1995) also used interviews to investigate Irish learners' production of French negation word $n e$.

Video recordings of student-professor conversations, designed to collect naturalistic spoken data, were analyzed to investigate ESL learners' production of suggestion and rejection in academic advising sessions (Salsbury \&Bardovi-Harlig, 1993). Ishida’s (2009) study used video recordings to investigate an American learner's production of Japanese sentence final particle ne. The participant self-recorded conversations with Japanese native speakers, and then the recordings were transcribed for analysis. In another study by Ishida 
(2011), video recordings of dinner talks between an American learner and her host mother were used to examine her response forms as a story recipient in L2 Japanese.

Only four studies examined development of pragmatic comprehension in the SA context (Bouton, 1992, 1994; Taguchi, 2008a, 2008b). These studies used multiple-choice tests to measure L2 learners' comprehension of conversational implicatures. In Bouton's studies (1992, 1994), ESL learners read written conversations in English, and then chose the accurate implied meaning encoded in each conversation. Taguchi (2008a, 200b) also used a multiple-choice test to measure Japanese learners' comprehension of indirect refusals and indirect opinions in L2 English. Different from Bouton's studies, target dialogues were presented aurally via computer.

Finally, seven studies examined development of pragmatic perception in the SA context on three aspects: sensitivity to pragmatic errors (Schauer, 2006a, 2006b), awareness of language variation (Kinginger \& Farrell, 2004; Kinginger \& Blattner, 2008; Kinginger, 2008), and perception of social status (Matsumura, 2001, 2003). Schauer (2006a, 2006b) adapted the video-and-questionnaire task developed by Bardovi-Harlig and Dornyei (1998) to assess German learners' sensitivity to pragmatic and grammatical errors in L2 English. The task consisted of video scenarios featuring interactions between a student and their peers, teachers, and staff members. A sample item in the task is seen on the next page (Schauer, 2006b, p. 144):

\begin{tabular}{|l|l|}
\hline \multicolumn{1}{|l|}{ Scenario 7} \\
Teacher: Anna, it's your turn to give \\
your talk.
\end{tabular}

In the table above, the target utterance for each scenario are given in bold, followed by two questions. The first question asked about appropriateness and correctness of the utterance, and the second asked about perceived severity of the error, if any. A post hoc interview was conducted to further probe how participants made their choices.

Semi-structured interviews were used in three studies that examined learners' development of perception of sociolinguistic forms (Kinginger \& Farrell, 2004; Kinginger \& Blattner, 2008; Kinginger, 2008). The interview was called Language Awareness Interview (LAI), which was comprised of six parts that targeted four different sociolinguistic forms (address forms, colloquial phrases, question forms and leave-taking expressions) (Kinginger, 2008). For example, in one section, participants gave the meaning of colloquial words, and told the interviewer in which situations these words were used. In another section, participants chose appropriate address form (tu or vous) according to situation. 
The third aspect of pragmatic perception investigated in previous studies was learners perception of social status (Matsumura, 2001, 2003). The participants were asked to choose appropriate expressions according to situation in a multiple-choice test. The test had 12 scenarios, each followed by four response choices. Each scenario represented one of three social statuses: talking to a supervisor (higher status), to a classmate (equal status), and to a first-year college student (lower status). The four response choices represented four types of advice-giving expressions: direct (e.g., the use of "should" without hedging), hedging (e.g., the use of "maybe," and "I think"), indirect (implicit advice-giving intention), and opting out (not giving advice).

In summary, the present synthesis found that speech acts are the primary focus of the studies conducted in the SA context. Other target pragmatic features include conversational implicatures, and sociolinguistic forms (e.g., address forms, colloquial words, modal expressions, negation word, sentence final particle, polite and plain speech style, listeners' response forms). In terms of modalities, pragmatic production is the main focus of previous studies, while studies about comprehension of conversational implicatures and perception of appropriateness of forms in situation are underrepresented in the existing literature.

Three types of instruments measure this aspect: measures with fixed answers (multiple-choice test, yes-no questions), measures eliciting target pragmatic features (DCT, multimedia elicitation task), and measures collecting naturalistic spoken data (role-play, semi-structured interview, audio and video recordings). The advantage of the first two types is that they can manipulate social variables in situation (e.g., social status, power relationship and personal distance), and collect comparable data from a large group of learners across time. Thus, the first two measures are appropriate for studies which aim to generalize group change in pragmatic competence over time. Moreover, the manipulation of social variables allows researchers to create different situation types (e.g. low-and high-imposition; low, high and equal social status). Therefore, findings can reveal the effect of the SA context in pragmatic development according to different task situations (varied in social variables).

However, one tradeoff is that the situations used in these controlled measures are not authentic, and there might be differences between learners' performance in imagined situations and in their real-life interactions. Another tradeoff is that controlled measures usually target fixed responses (e.g., one accurate implicature of a conversation, one appropriate expression in a target situation). Thus, these measures are not sensitive to individual differences in their perception of the social situation.

Contrary to these controlled measures, role-play, OPI, semi-structured interviews are designed to elicit target pragmatic features in interaction (for reviews of data collection methods of L2 pragmatics, see FélixBrasdefer, 2010; Roever, 2011). Interviews often include open-ended questions, which give learners some leeway in saying things freely. Similarly, audio and video recordings of daily conversations are almost completely naturalistic. The main advantage is that these measures expose learners to real-time communication, which requires learners to perform pragmatic functions in an on-going interaction while keeping up with the flow of conversation. Moreover, these measures do not target fixed response forms, which allow flexibility in target pragmatic functions. As such, these measures are suitable to capture individual variations in pragmatic development in the SA context.

\section{Synthesis Question Two}

The second synthesis question asks whether adult L2 learners improve their pragmatic competence in the SA context over time. Previous findings on the effect of the SA context on pragmatic development can be categorized into four groups: 1) a positive effect; 2) almost no effect; 3) mixed effects depending on the aspect 
of pragmatic features examined; and 4) complex findings due to individual differences.

Positive effect. Three studies revealed an overall trajectory toward target-like norms (Matsumura, 2001, 2003; Schauer, 2006a), showing a facilitative role of the SA context in pragmatic development. Matsumura (2001), for example, investigated Japanese learners' change in the perception of English advice-giving expressions in situation. Japanese learners of English in Japan and Canada (EFL and ESL groups) took a multiple-choice test four times over an eight-month period. The test required participants to choose appropriate advice-giving expressions according to context. Findings revealed that more ESL students chose target-like expressions as time passed, suggesting that the SA context facilitates ESL learners' development of pragmatic perception. In Matsumura (2003), the same multiple-choice test was used to examine effects of general proficiency (determined by TOEFL) and exposure to target language (measured by a self-report questionnaire) on ESL learners' development of pragmatic perception over an eight-month study in Canada. Results showed that exposure to target language had a greater effect on pragmatic development than general proficiency, and there was an indirect effect of general proficiency on pragmatic development via exposure to target language.

Similarly, Schauer (2006a) examined development of sensitivity to pragmatic and grammatical errors in L2 English. 16 ESL learners in England and 17 EFL learners in Germany took a video-and-questionnaire task at the beginning and the end of a nine-month period. Task items contained utterances with either grammatical or pragmatic errors in speech acts of apology, refusal, request, and suggestion. Participants were asked to decide appropriateness and correctness of the utterances, and rated severity of errors. Results showed that, compared with EFL learners, ESL learners were more sensitive to pragmatic errors, and they reached the native speaker level at the end of their stay in England. ESL learners also identified more pragmatic than grammatical errors. Post hoc interview showed that interactions with and observations of native speakers accounted for learners' development in the SA context.

Almost no effect. The facilitation effect of the SA context found in Matsumura and Schauer's studies could be explained by the nature of the target-language environment that provides many opportunities to promote pragmatic perception. However, three other studies revealed almost no effect of the SA context on pragmatic development (Barron, 2006; Iwasaki, 2010; Regan, 1995). For example, Regan (1995) used interviews to investigate six Irish learners' change in the use of French negation word ne during a one-year study in France. The negation word ne is typically deleted in informal style but not in formal style of French. Interviews were conducted both before and after SA. Results showed that learners overused lexicalized phrases without $n e$, which led to a high rate of ne deletion in formal style of French. Moreover, this phenomenon occurred even more at post-study abroad, indicating a change away from native norms.

Similarly, Barron's (2006) study used DCT to examine 33 advanced Irish learners' change in the production of German address forms sie (polite/distant pronoun) and $d u$ (intimate/simple pronoun) over a 10-month stay in Germany. Data were collected before, during and toward the end of SA. She found that learners overused sie in five of the six target situations where $d u$ was appropriate, and they were not able to switch between sie and $d u$ within a dialogue even at the end of their stay. In other words, production of German address forms in the SA context remained non-native-like throughout the time.

Similar findings were found in Iwasaki's (2010) study. She used OPI to investigate five male American students' change in the use of Japanese polite and plain speech style over a one-year study in Japan. Findings showed that all five participants could not use the polite forms (masu /desu) in a native-like manner prior to SA. By the end of SA, two of the five students used the plain style as their base style when the polite style was 
the norm in interview. These findings suggest that the development of speech style takes time even in a targetlanguage country and may differ across different individuals.

Mixed effects on different aspects of pragmatic features. In fact, a large number of previous studies revealed a nuanced picture of pragmatic gains in the SA context, showing that SA effects vary according to different aspects of pragmatic features. Among these studies, a series of studies on production of speech acts demonstrated that the effect of the SA context differed across types of speech acts examined in the studies (Bardovi-Harlig \& Hartford, 1993; Barron, 2003, 2007; Bataller, 2010; Cole \& Anderson, 2001; Schauer, 2006b, 2007; Warga \& Scholmberger, 2007). Bardovi-Harlig and Hartford (1993), for example, analyzed naturalistic advising sessions between student and professor to investigate $10 \mathrm{ESL}$ learners' development of suggestion and rejection over a one-semester study in a U.S. university. Findings showed that, as time passed, there was an increase in learners' use of suggestion, but the forms of suggestion remained non-native like because of the significantly low use of mitigators (e.g., "maybe", "I was wondering") when making a suggestion to a professor. This non-native-like production remained the same over one semester. In contrast, learners' production of rejection became more native-like over time: they used less rejection and more credible reasons to reject professor's suggestion (e.g., having taken a similar course at another university). These different patterns of development between suggestion and rejection indicate that speech acts may differ in their degree of development: some speech acts may develop more quickly in the SA context than others.

Similarly, Cole and Anderson's (2001) study revealed Japanese ESL learners' slow development of production of downgraders in request (e.g., politeness marker "please", modal verb "could") over a 10-month study abroad. They used DCT which included scenarios of different interlocutor relationships: interactions with teacher or homestay parents (higher social status) and classmates (equal social status). 35 Japanese learners of English, who studied in New Zealand and Canada for 10 months, took the DCT before and after SA. Results showed that learners' production of request remained non-native-like after SA because of the significantly low use of downgraders in all situations except in the situation of talking to a teacher. Learners' slow development in the use of downgraders in request (Cole \& Anderson2001) and mitigators in suggestion (Bardovi-Harlig \&Hartford, 1993) may be because learners are still lacking appropriate linguistic resources to produce more complex pragmalinguistic forms in situation.

Salsbury and Bardovi-Harlig's (2000) study about English modal expressions is another such example. In their study, eight ESL learners in a U.S. university were interviewed monthly over one year. After examining their use of six modal expressions ("maybe", "think", "can", "will", "would" and "could"), they found that learners' use of maybe and think, can and well significantly outperforming their use of would and could in terms of token frequency. The learners began using think and maybe by the end of the first month. Shortly after that, they started to produce can and will. Finally, after six months, they began using would and could.

Consistent with studies on pragmatic production in the SA context, differential rates of gain were also observed in studies on pragmatic comprehension (Bouton, 1992, 1994; Taguchi, 2008a, 2008b). For example, Bouton (1992) used a multiple-choice test to assess ESL learners' ability to understand implicatures in written conversations. 30 participants took the test twice over a span of four and a half years. Results showed that the learners improved their pragmatic comprehension over time, but seven of the 33 test items remained problematic for them in the second test. Among those problematic items, five were indirect criticism. These findings indicate that learners' development is affected by types of implicature.

Similarly, Taguchi's (2008a) used a computerized listening task to measure 57 ESL (in America) and 60 EFL (in Japan) learners' change in comprehending indirect refusals and opinions over seven weeks. Indirect 
refusals are conventional, because they are associated with routinized discourse patterns (e.g., giving a reason for the refusal). In contrast, indirect opinions are unconventional, because they do not adhere to specific linguistic forms (e.g., indicating a negative opinion of a movie by saying "I was glad when the movie was over."). Findings showed that both ESL and EFL groups achieved significant gains in accuracy and speed (measured by response time) of pragmatic comprehension over time. However, ESL group demonstrated a larger gain in speed than in accuracy of comprehension, and they did not improve as much as EFL group in accuracy of comprehension. These findings suggest that the SA context has a greater effect on speed than on accuracy in comprehension of pragmatic meaning.

In another study, Taguchi (2008b) focused on Japanese learners' gains on pragmatic comprehension over a four-month study in U.S.A. The same multiple-choice task was administered to 44 Japanese ESL learners three times during SA. Consistent with Taguchi (2008a), results showed that there were significant gains in both accuracy scores and response time, but the magnitude of gain in response time was larger than that of accuracy scores. When indirect refusals and indirect opinions were compared, significant gains were found in both accuracy and response time for comprehension of indirect refusals, but not for indirect opinions. In other words, the learners achieved larger gains in comprehending conventional pragmatic meaning (indirect refusals) than unconventional pragmatic meaning (indirect opinions) in the SA context over time.

Complex findings due to individual differences. Pragmatic development in the SA context not only varies according to the nature of target pragmatic features (complexity of pragmaliguistic forms, degree of directness and conventionality, accuracy and speed), but also differs across individuals. Six studies have showed that individual differences play an important role in pragmatic development in the SA context (Ishida, 2009, 2011; Kinginger, 2008; Kinginger \& Blattner, 2008; Kinginger \& Farrell, 2004).

For example, Kinginger and Farrrel's (2004) investigated American learners' development of perception of French second person pronouns $t u$ (used in informal situation, indicating close relationship) and vous (used in formal situation, indicating social distance). Eight American learners completed the Language Awareness Interview (LAI) before and at the end of their one-year study in France. Participants chose between $t u$ and vous during the interview, and told interviewers how they made their choices. Findings revealed that the learners improved their perception of $t u$ and vous in situation over time. Moreover, the learners who had more interactions with native speakers improved more. For example, one participant, Bill, chose to stay with a French family. He was actively involved in social events with French people, and distanced himself from his American peers. As such, Bill understood the distinction between $t u$ and vous by the end of SA. In contrast, another participant, Brianna, shared an apartment with other American students. Her network with native speakers was limited to people she met in service encounters and class, and she maintained close contact with her American peers. The limited exposure to French accounted for her slow development in knowledge of $t u$ and vous. These two cases suggest that personal experiences affect development of pragmatic perception.

Similarly, Kinginger's (2008) study used the same instrument to investigate 24 American learners' gains in awareness of language variation in French (address forms, colloquial phrases, question forms and leavetaking expressions) over a semester-long study in France. Participants took the interview before and at the end of SA. Findings revealed a notable gain in every target pragmatic feature, but there were great individual differences. Qualitative data showed that the learners having a large social network with native speakers improved most, while the learners having a limited network with native speakers improved least. For example, one participant, Louis, actively developed a social network with French peers by attending local activities and doing projects with French classmates. As a result, he achieved a great gain in awareness of language variation at the end of SA. In contrast, another participant, Beatrice, isolated herself from her host family, and spent 
most of her spare time with American peers. Thus, she improved very little at the end of SA. These two cases suggest that individual differences in access to opportunities for practice affects pragmatic gains in the SA context.

Consistent with the two studies on development of pragmatic perception in the SA context above, Ishida (2009) used self-recorded conversations to investigate an American learner's change in the use of Japanese sentence final particle ne over his nine-month study in Japan. Conversation analysis revealed the microgenetic development of ne in the SA context. In the first three months, the learner was able to use ne to initiate a topic. In the fifth month as he became more familiar with people in the target community, he became able to show agreement by using soo desu ne when talking with native speakers. In the eighth month, he became able to show alignment with ne-ending questions in conversations with native speakers, because he had established a membership in the target community. In other words, as personal engagement in the target community increased, the learner became able to improve his participation in conversations with native speakers from a peripheral listener to a co-constructor of interaction.

In summary, mixed findings on pragmatic gains in the SA context found in these studies reveal many factors that influence pragmatic development in the SA context, including different aspects of pragmatic features such as degree of directness and conventionality, accuracy and speed aspects of pragmatic performance, and individual differences in exposure to target language, opportunities for practice, and engagement in interaction. In essence, pragmatic development in the SA context relies on the complex interplay between the nature of target language features, language users, and the context of language use (Kasper, 1992; Kasper \& Rose, 2002; Taguchi, 2010; Thomas, 1983).

\section{Summary of Synthesis Results and Future Research Directions}

The purpose of this synthesis was twofold: 1) to examine target pragmatic features investigated in previous studies and instrument used to measure these features; and 2) to investigate whether adult L2 learners improve on pragmatic competence in the SA context over time.

Regarding target pragmatic features, speech acts are the main focus of previous studies (12 out of 26 studies). Relatively few studies have examined conversational implicatures (4 out of 26 studies), and sociolinguistic forms such as address forms (3 out of 26 studies), colloquial words ( 2 out of 26 studies) , model expressions ( 1 out of 26 studies) and listeners' response forms ( 1 out of 26 studies). Therefore, more studies should investigate pragmatic competence beyond speech acts, because the ability to comprehend implicatures and sociolinguistic competence are important aspects of pragmatic competence. With regard to measurement, major instrument used in previous studies was designed to collect performance data on pragmatic competence (e.g., DCT, multiple-choice task, OPI, and role-play), with only a few studies using post hoc interviews to examine the rationale behind learners' pragmatic performance and their access to pragmatic resources in the SA context (Schauer 2006a; Kinginger, 2008; Kinginger \& Blattner, 2008; Kinginger \& Farrell, 2004). It is critical to understand why learners perform pragmatic functions in a certain manner, especially when they make pragmatic errors. In conjunction with performance measure, use of interviews can shed light on what is a bigger obstacle for learners when performing pragmatic functions: linguistic forms (pragmalinguistics) or social norms (sociopragmatics). Moreover, to better understand how pragmatic resources in the SA context (e.g. the amount and quality of interaction, opportunities for practice and engagement in interaction) may contribute to the development of pragmatic competence, learners' individual access to the target community ought to be documented via interview, observation and survey. Data collected by these measures can reveal learners' actual interactions in the SA context (e.g. frequency of 
encounters of different situations, social network with native speakers, the amount of time using the target language), which can shed light on what pragmatic resources in the SA context could have a large effect on pragmatic development.

In general, findings of previous studies support a facilitative role of the SA context in pragmatic development, but pragmatic development occurs at different rates on different aspects of pragmatic features (Bardovi-Harlig \& Hartford, 1993; Barron, 2003, 2007; Bataller, 2010; Bouton, 1992, 1994; Cole \& Anderson, 2001; Salsbury \& Bardovi-Harlig's study, 2000; Schauer, 2006b, 2007; Taguchi, 2008a, 2008b; Warga \& Scholmberger, 2007). For example, Bardovi-Harlig and Hartford's (1993) study showed that by the end of SA, ESL learners' production of rejection in advising sessions became native-like, but their suggestion remained the same (low use of mitigators). Learners were able to observe and imitate their advisors' pragmatic performance in the sessions, which may account for their native-like production of rejection at the end of SA. However, complex speech acts (e.g., suggestion) requires a mastery of mitigating forms as well as knowledge of appropriateness of the forms in situation, which require adequate practice in formal settings like advising sessions. However, learners' daily life may include more interactions in informal than formal situations (e.g., chatting with friends and classmates, dinner talks with host families, and talking with people in service encounters). Hence, it is possible that, because of their low engagement in formal situation, learners' use of mitigators in suggestion didn't improve in this study. Similarly, Cole and Anderson's (2001) study revealed ESL learners' use of downgraders in request remained the same over a 10-month study in New Zealand and Canada. All these findings suggest that complexity of linguistic forms required for target speech acts affect rates of pragmatic gain in the SA context over time.

Other attributes of target pragmatic features (degree of directness and conventionality in meaning, accuracy and speed) also affect gains in implicature comprehension in the SA context (Bouton, 1992, 1994; Taguchi, 2008a, 2008b). For example, Bouton's (1992) study revealed that ESL learners still had problem with indirect criticism (5 out of 33 test items) over a SA period of four and a half years. Similarly, Taguchi's (2008a, 2008b) two studies revealed that ESL learners had a larger gain in speed (measured in response time) than in accuracy of pragmatic comprehension during SA. In terms of types of implicature (degree of conventionality), significant gains was found in both accuracy and response time for comprehension of indirect refusals (conventional), but not for indirect opinions (unconventional). All findings suggest that learners in the SA context cannot achieve equal gains in different aspects of pragmatic comprehension (degree of directness and conventionality, accuracy and speed).

In essence, not all pragmatic features can develop to the same degree or at the same pace over the same SA period. This is in part due to the nature of pragmatic features (e.g., complexity of linguistic forms; degree of directness and conventionality, accuracy and speed). These findings call for future studies to investigate different gains across different aspects of pragmatic competence, which may shed light on how the SA context affects the development of pragmatic competence reflected in different constructs of pragmatic features.

Previous findings also support the claim that exposure to target language benefits pragmatic development (Matsumura, 2001, 2003; Schauer, 2006a). In general, the SA context can provide ample pragmatic input (e.g., opportunities for learners to interact with and observe native speakers), but their actual access to these pragmatic resources differ among individuals (Ishida, 2009, 2011; Kinginger, 2008; Kinginger \& Blattner, 2008; Kinginger \& Farrell, 2004). For example, Kinginger's (2008) study showed that having a large social network with native speakers in the SA context was critical to learners' gain in awareness of language variation in French over time, because a large network with native speakers can provide adequate opportunities for interactions, which may lead to pragmatic gains. However, learners' actual utilization of pragmatic resources 
(e.g., host families; native-speaker friends; local activities, field trips) is determined by their stance and engagement in target-language community. For example, Ishida's (2009) study revealed that, as time passed, the participant gradually established a membership in the target community, and was able to develop his ability to use Japanese sentence particle ne in responses from playing a passive to an active role in meaning construction in communication. Therefore, more studies should investigate the relationship between pragmatic gains and learners' individual access to pragmatic resources in target-language country, which may shed light on how individual differences affect pragmatic development in the SA context.

In contrast, three studies revealed little effect of the SA context on pragmatic development (Barron, 2006; Iwasaki, 2010; Regan, 1995). For example, Regan's (1995) studies showed that learners had a remarkable increase of deletion of French negation word ne in formal style by the end of their one-year stay in France, showing a non-native-like performance Similarly, Iwasaki's (2010) study documented that two of the five L2 Japanese learners used the plain style as their base style when the polite style was the norm in conversations with a teacher even at the end of their one-year study in Japan. These seemingly contradictory findings may be due to the quality and nature of learners' interactions in the SA context. Learners often engage in a variety of informal interactions (e.g., chatting with native-speaker friends, dinner talk with host families, and talking with people in service encounters). Because of these ample opportunities to practice target language in informal situations, learners might overuse informal linguistic forms and underuse formal linguistic forms. Future studies should pay closer attention to the relationship between pragmatic gains, the nature of interactions in the SA context and the nature of target pragmatic features.

To reconcile the divergent conclusions gleaned from previous studies, it is helpful to consider studies that report the significant role of individual differences on pragmatic development in the SA context. Due to variability among learners in their engagement in interaction, identities in the community, and motivation for L2 learning, it is understandable that not all learners can achieve equal degree of pragmatic gain over the same SA period (e.g., Ishida, 2009; Kinginger \& Farrell, 2004). Furthermore, because pragmatic development is likely to be affected by all of these individual difference factors, qualitative studies that provide a rich description of context, learners' background, engagement in interaction, and other individual experiences are necessary in future research. In summary, future studies should focus on the relationship between pragmatic gains and variables both at the contextual and individual level because the interdependence of these variables in the SA context account for the effect of the context on the development of pragmatic competence. Another direction of future studies would be to investigate the relationship between affordances of the SA context and learners' source attribution when completing pragmatic tasks. Findings of these studies will shed light on what pragmatic sources can be transformed to perform pragmatic functions in a designed pragmatic task.

\section{References}

Bachman, L. F. (1990). Fundamental considerations in language testing. Oxford, UK: Oxford University Press.

Bachman, L. F., \& Palmer, A. S. (1996). Language testing in practice. Oxford: Oxford University Press.

Bachman, L. F., \& Palmer, A. S. (2010). Language testing in practice. Oxford, UK: Oxford University Press.

*Bardovi-Harlig, K. , \& Dornyei, Z. (1998). Do language learners recognize pragmatic violations? Pragmatic vs. grammatical awareness in instructed L2 learning. TESOL Quarterly, 32(2), 233-259. 
*Bardovi-Harlig, K., \& Hartford, B. (1993). Learning the rules of academic talk: A longitudinal study of pragmatic development. Studies in Second Language Acquisition, 15(3), 279-304.

*Barron, A. (2003). Acquisition in interlanguage pragmatics: Learning how to do things with words in a study abroad context. Amsterdam/ Philadelphia: John Benjamins.

*Barron, A. (2006). Learning to say 'you' in German: The acquisition of sociolinguistic competence in a study abroad context. In M. DuFon and E. Churchill (Eds.), Language learners in study abroad contexts (pp. 5988). Clevedon, UK: Multilingual Matters.

*Barron, A. (2007). “Ah no honestly we're okay:” Learning to upgrade in a study abroad context. Intercultural Pragmatics, 4, 129-166.

*Bataller, R. (2010). Making a Request for a Service in Spanish: Pragmatic Development in the Study Abroad Setting. Foreign Language Annals, 43, 160-175.

*Bouton, L. (1992). The interpretation of implicature in English by NNS: Does it come automatically without being explicitly taught? Pragmatics and Language Learning, 3, 53-65.

* Bouton, L. (1994). Conversational implicature in a second language: Learned slowly when not deliberately taught. Journal of Pragmatics, 22, 157-167.

Canale, M., \& Swain, M. (1980). Theoretical bases of communicative approaches to second language teaching and testing. Applied Linguistics, 1, 1-47.

*Cole, S., \& Anderson, A. (2001). Requests by young Japanese: A longitudinal study. The Language Teacher, 25(8), 7-11.

Collentine, J. (2009). Study Abroad Research: Findings, Implications, and Future Directions. In C. Doughty \& M. Long (Eds.), The handbook of language teaching (pp. 218-233). Malden, MA: Blackwell.

Collentine, J., \& Freed, B. (2004). Learning contexts and its effects on second language acquisition. Studies in Second Language Acquisition, 26, 153-172.

Félix-Brasdefer, J. C. (2010). Data collection methods in speech act performance: DCTs, role plays, and verbal reports. In E. Usó Juán and A. Martínez-Flor (Eds), Speech act performance: Theoretical, Empirical, and methodological issues. Amsterdam/Philadelphia: John Benjamins.

Freed, B. (1995). Second language acquisition in a study abroad context. Amsterdam/Philadelphia: John Benjamins.

Grice, H. P. (1975). Logic and conversation. In P. Cole \& J. L. Morgan (Eds.), Syntax and semantics 3 (pp.41589). New York: Academic Press.

*Ishida, M. (2009). Development of interactional competence: Changes in the use of ne in L2 Japanese during study abroad. In H. T. Nguyen \& G. Kasper (Eds.), Talk-in-interaction: Multilingual perspectives (pp. 351-385). Honolulu, HI: University of Hawai'I, National Foreign Language Resource Center.

*Ishida, M. (2011). Engaging in another person's telling as a recipient in L2 Japanese: Development of interactional competence during one-year study-abroad. In G. Pallotti \& J. Wagner (Eds.), L2 learning as 
social practice: Conversation-analytic perspectives. Honolulu, HI: University of Hawai'i, National Foreign Language Resource Center.

*Iwasaki, N. (2010). Style Shifts among Japanese Learners before and after Study Abroad in Japan: Becoming Active Social Agents in Japanese. Applied Linguistics, 31, 45-71.

Kasper, G. (1992). Pragmatic transfer. Second Language Research, 8, 203-231.

Kasper, G., \& Rose, K. (1999). Pragmatics and SLA. Annual Review of Applied Linguistics, 19, 81-104.

Kasper, G., \& Rose, K. (2002). Pragmatic development in a second language. Language Learning, 53(Suppl. 1), 1-352.

Kasper, G., \& Roever, C. (2005). Pragmatics in second language learning. In E. Hinkel (Ed.), Handbook of research in second language teaching and learning (pp.317-334). New Jersey: Lawrence Erlbaum Associates, Inc.

*Kinginger, C. (2008). Language learning in study abroad: Case studies of Americans in France. Modern Language Journal Monograph Series, 1.

Kinginger, C. (2009). Language learning and study abroad: a critical reading of research. Basingstoke, UK: Palgrave Macmillan.

*Kinginger, C., \& Blattner, G. (2008). Development of sociolinguistic awareness in study abroad. In L. Ortega \& H. Byrnes (Eds.), Longitudinal studies and advanced L2 capacities (pp. 223-246). New York, NY: Routledge.

*Kinginger, C, \& Farrell, K. (2004). Assessing development of metapragmatic awareness in study abroad. Frontiers: The interdisciplinary journal of study abroad, 10, 19-42.

Leech, G. (1983). Principles of Pragmatics. London, UK: Longman.

*Masuda, K. (2011). Acquiring interactional competence in a study abroad context: Japanese language learners' use of the interactional particle ne. Modern Language Journal, 95, 519-540.

*Matsumura, S. (2001). Learning the rules for offering advice: A quantitative approach to second language socialization. Language Learning, 51, 635-679.

*Matsumura, S. (2003). Modeling the relationship among interlanguage pragmatic development, L2 proficiency, and exposure to L2. Applied Linguistics, 24, 465-491.

Norris, M., \& Ortega, L. (2006). Synthesizing research on language learning and teaching. Cambridge, UK: Cambridge University Press.

*Regan, V. (1995). The acquisition of sociolinguistic native speech norms. In B. Freed (Ed.), Second language acquisition in a study abroad context (pp. 245-267). Amsterdam/Philadelphia: John Benjamins.

Roever, C. (2011). Testing of second language pragmatics: Past and future. Language Testing, 28(4), 463-481.

* Salsbury, T., \& Bardovi-Harlig, K. (2000). Oppositional talk and the acquisition of modality in L2 English. In B. Swierzbin, F. Morris, M. E. Anderson, C. A. Klee, \& E. Tarone (Eds.), Social and cognitive factors in 
second language acquisition: Selected proceedings of the 1999 second language research forum (pp. 57-76). Somerville, MA: Cascadilla Press.

*Sawyer, M. (1992). The development of pragmatics in Japanese as a second language: The sentence-final particles ne. In G. Kasper (Ed.), Pragmatics of Japanese as native and target language (pp.83-125). Honolulu, HI: University of Hawai' $i$.

*Schauer, G. (2006a). Pragmatic awareness in ESL and EFL contexts: Contrast and development. Language Learning, 56, 269-318.

*Schauer, G. (2006b). The development of ESL learners' pragmatic competence: A longitudinal investigation of awareness and production. Pragmatics and Language Learning, 11, 135-161.

*Schauer, G. (2007). Finding the right words in the study abroad context: The development of German learners' use of external modifiers in English. Intercultural Pragmatics, 4, 193-220.

*Taguchi, N. (2008a). The role of learning environment in the development of pragmatic comprehension: A comparison of gains between EFL and ESL learners. Studies in Second Language Acquisition, 30, 423-452.

*Taguchi, N. (2008b). Cognition, language contact, and the development of pragmatic comprehension in a study-abroad context. Language Learning, 58, 33-71.

Taguchi, N. (2010). Longitudinal studies in interlanguage pragmatics. In A. Trosborg (ed.), Handbook of pragmatics vol.7: Pragmatics across languages and cultures (pp.333-361). Berlin, Germany: Mouton de Gruyter.

Thomas J. (1983). Cross-cultural pragmatic failure. Applied linguistics, 4, 91-112.

*Warga, M., \& Scholmberger, U. (2007). The acquisition of French apologetic behavior in a study abroad context. Intercultural Pragmatics, 4, 221-251. 


\section{Appendix A: Study Coding Scheme}

Author and publication date
Research questions
Target language
Target pragmatic features
Instrument/Data
Data collection points
Sample size
L2 proficiency levels
Length of study abroad
Findings




\section{Appendix B: Table of the Study Profile}

Acronyms: SA= study abroad; DCT= discourse completion task; OPI= Oral Proficiency Interview; LAI =Language Awareness Interview; TFI=Test Francais International; MCT=Multiple-choice test; MET= Multimedia Elicitation Task; $P=$ production; $C=$ comprehension; $P E=$ perception.

\begin{tabular}{|c|c|c|c|c|c|c|c|}
\hline Study & $\begin{array}{c}\text { Target } \\
\text { Language }\end{array}$ & Length of SA & $\begin{array}{c}\text { Target } \\
\text { Pragmatic } \\
\text { Feature }\end{array}$ & Modality & $\begin{array}{c}\text { L2 } \\
\text { Proficiency }\end{array}$ & Instrument/Data & $\begin{array}{c}\text { Data } \\
\text { Collection } \\
\text { Points }\end{array}$ \\
\hline $\begin{array}{l}\text { Bardovi- } \\
\text { Harlig \& } \\
\text { Hartford. } \\
\text { (1993) }\end{array}$ & English & 1 semester & $\begin{array}{l}\text { Suggestion } \\
\text { \& Rejection }\end{array}$ & $P$ & Advanced & Video recording & 2 \\
\hline $\begin{array}{l}\text { Barron } \\
\text { (2003) }\end{array}$ & German & 10 months & Request & $P$ & Advanced & DCT & 3 \\
\hline $\begin{array}{l}\text { Barron } \\
(2006)\end{array}$ & German & 10 months & $\begin{array}{l}\text { Address } \\
\text { forms }\end{array}$ & $\mathrm{P}$ & Advanced & DCT & 3 \\
\hline $\begin{array}{l}\text { Barron } \\
(2007)\end{array}$ & German & 10 months & $\begin{array}{l}\text { Upgraders of } \\
\text { request }\end{array}$ & $P$ & Advanced & DCT & 3 \\
\hline $\begin{array}{l}\text { Bataller } \\
(2010)\end{array}$ & Spanish & 4 months & Request & $P$ & Not given & Role-play & 2 \\
\hline $\begin{array}{l}\text { Bouton } \\
\text { (1992) }\end{array}$ & English & $41 / 2$ years & Implicatures & C & Mixed & MCT & 2 \\
\hline $\begin{array}{l}\text { Bouton } \\
\text { (1994) }\end{array}$ & English & $\begin{array}{l}4 \frac{1}{2} 2 \text { years } \\
\& 17 \text { months }\end{array}$ & Implicatures & C & Mixed & MCT & 2 \\
\hline $\begin{array}{l}\text { Cole \& } \\
\text { Anderson } \\
(2001)\end{array}$ & English & 10 months & Request & $\mathrm{P}$ & Not given & DCT & 2 \\
\hline $\begin{array}{l}\text { Ishida } \\
\text { (2009) }\end{array}$ & Japanese & 9 months & $\begin{array}{l}\text { Sentence } \\
\text { final particle } \\
\text { ne }\end{array}$ & $P$ & Not given & Video recording & 8 \\
\hline $\begin{array}{l}\text { Ishida } \\
\text { (2011) }\end{array}$ & English & 9 months & $\begin{array}{l}\text { Listeners' } \\
\text { response } \\
\text { forms }\end{array}$ & $\mathrm{P}$ & Not given & Video recording & 7 \\
\hline $\begin{array}{l}\text { Iwasaki } \\
\text { (2010) }\end{array}$ & Japanese & 2 semesters & $\begin{array}{l}\text { Polite \& plain } \\
\text { speech style }\end{array}$ & $\mathrm{P}$ & $\begin{array}{l}\text { Intermediate } \\
\text { to advanced }\end{array}$ & OPI & 2 \\
\hline $\begin{array}{l}\text { Kinginger } \\
(2008)\end{array}$ & French & 2 semesters & $\begin{array}{l}\text { Address } \\
\text { forms; } \\
\text { colloquial } \\
\text { words \& } \\
\text { leave-taking }\end{array}$ & PE & Mixed & $\begin{array}{l}\text { 1) LAI } \\
\text { 2) TFI } \\
\text { 3) Interview } \\
\text { 4) Journal } \\
\text { 5) Logbook } \\
\text { 6) Field note }\end{array}$ & $\begin{array}{c}2 \text { (LAI, } \\
\text { TFI) }\end{array}$ \\
\hline $\begin{array}{l}\text { Kinginger\& } \\
\text { Farrell } \\
(2004)\end{array}$ & French & 2 semesters & $\begin{array}{l}\text { Address } \\
\text { forms }\end{array}$ & PE & Mixed & $\begin{array}{l}\text { 1) LAI } \\
\text { 2) TFI } \\
\text { 3) Interview } \\
\text { 4) Journal } \\
\text { 5) Logbook } \\
\text { 6) Field note }\end{array}$ & $\begin{array}{l}2 \text { (LAl, } \\
\text { TFI) }\end{array}$ \\
\hline
\end{tabular}




\begin{tabular}{|c|c|c|c|c|c|c|c|}
\hline $\begin{array}{l}\text { Kinginger\& } \\
\text { Blattner } \\
\text { (2008) }\end{array}$ & French & 1 semester & $\begin{array}{l}\text { Colloquial } \\
\text { phrases }\end{array}$ & $\mathrm{PE}$ & Mixed & $\begin{array}{l}\text { 1) LAI } \\
\text { 2) TFI } \\
\text { 3) Interview } \\
\text { 4) Journal } \\
\text { 5) Logbook } \\
\text { 6) Field note }\end{array}$ & $\begin{array}{l}2 \text { (LAI, } \\
\text { TFI) }\end{array}$ \\
\hline $\begin{array}{l}\text { Masuda } \\
\text { (2011) }\end{array}$ & Japanese & 5 weeks & $\begin{array}{l}\text { Sentence } \\
\text { final particle } \\
\text { ne }\end{array}$ & P & Intermediate & Audio recording & 2 \\
\hline $\begin{array}{l}\text { Matsumura } \\
(2001)\end{array}$ & English & 8 months & $\begin{array}{l}\text { Advice- } \\
\text { giving }\end{array}$ & $\mathrm{PE}$ & Mixed & MCT & 4 \\
\hline $\begin{array}{l}\text { Matsumura } \\
(2003)\end{array}$ & English & 8 months & $\begin{array}{l}\text { Advice- } \\
\text { giving }\end{array}$ & $\mathrm{PE}$ & Mixed & MCT & 4 \\
\hline $\begin{array}{l}\text { Regan } \\
(1995)\end{array}$ & French & 1 year & $\begin{array}{l}\text { Negation } \\
\text { word ne }\end{array}$ & $\mathrm{P}$ & Not given & Interview & 2 \\
\hline $\begin{array}{l}\text { Salsbury \& } \\
\text { Bardovi- } \\
\text { Harlig } \\
(2000)\end{array}$ & English & 1 year & $\begin{array}{l}\text { Modal } \\
\text { expressions }\end{array}$ & $P$ & Beginning & Interview & 12 \\
\hline $\begin{array}{l}\text { Sawyer } \\
\text { (1992) }\end{array}$ & Japanese & 1 year & $\begin{array}{l}\text { Sentence } \\
\text { final particle } \\
\text { ne }\end{array}$ & P & Not given & Interview & 4 \\
\hline $\begin{array}{l}\text { Schauer } \\
\text { (2006a) }\end{array}$ & English & 9 months & $\begin{array}{l}\text { Pragmatic } \\
\text { errors }\end{array}$ & $\mathrm{PE}$ & Not given & $\begin{array}{l}\text { 1) Video-and- } \\
\text { questionnaire } \\
\text { task } \\
\text { 2) Interview }\end{array}$ & 2 \\
\hline $\begin{array}{l}\text { Schauer } \\
\text { (2006b) }\end{array}$ & English & 1 year & $\begin{array}{l}\text { Pragmatic } \\
\text { errors } \\
\& \text { request }\end{array}$ & $\begin{array}{l}\mathrm{PE} \\
\& \mathrm{P}\end{array}$ & Not given & $\begin{array}{l}\text { 1) Video-and- } \\
\text { questionnaire } \\
\text { task } \\
\text { 2) MET }\end{array}$ & 2 \\
\hline $\begin{array}{l}\text { Schauer } \\
\text { (2007) }\end{array}$ & English & 1 year & $\begin{array}{l}\text { External } \\
\text { modifiers of } \\
\text { request }\end{array}$ & $P$ & Not given & MET & 2 \\
\hline $\begin{array}{l}\text { Taguchi } \\
\text { (2008a) }\end{array}$ & English & 7 weeks & Implicatures & C & Beginning & $\begin{array}{l}\text { Pragmatic } \\
\text { listening task }\end{array}$ & 2 \\
\hline $\begin{array}{l}\text { Taguchi } \\
\text { (2008b) }\end{array}$ & English & 4 months & Implicatures & C & Beginning & $\begin{array}{l}\text { 1) Pragmatic } \\
\text { listening task } \\
\text { 2) Lexical } \\
\text { access test } \\
\text { 3) Language } \\
\text { contact survey }\end{array}$ & 3 \\
\hline $\begin{array}{l}\text { Warga \& } \\
\text { Scholmber } \\
\text { ger (2007) }\end{array}$ & French & 10 months & Apology & $P$ & $\begin{array}{l}\text { Intermediate } \\
\text { to advanced }\end{array}$ & DCT & 6 \\
\hline
\end{tabular}

